\title{
Pengaruh Model Pembelajaran Sains Teknologi Masyarakat (STM) dalam Meningkatkan Kemampuan Literasi Sains Siswa di MTsN 1 Konsel
}

\author{
Yuvita Ayuningtyas ${ }^{1}$; Ismaun ${ }^{2}$; Marlina Gazali ${ }^{2}$; Jumarddin La Fua ${ }^{2}$ \\ 1) Alumni Prodi Tadris IPA, Fakultas Tarbiyah dan Ilmu Keguruan (FTIK), Institut Agama Islam Negeri (IAIN) \\ Kendari; \\ ${ }^{2)}$ Dosen Prodi Tadris IPA, FTIK, IAIN Kendari \\ Email Korespondensi : ismaun.kim@gmail.com
}

\begin{abstract}
This article is a quantitative study aimed to find out the effectiveness of learning using the Community Technology Science (STM) learning model on the theme of environmental pollution to increase the ability of science literacy in grade VII students. Samples taken were students of MTS Negeri 1 Counseling class VII A and VII C even semester semester 2018/2019. The research design used was posttest only control group design, which implements learning by using the STM learning model in the experimental class and the control class that applies Conventional learning. Data collection techniques used are collection techniques using documentation, observation and tests. The data taken is the result of observations measuring the ability of students' scientific literacy and learning outcomes. The ability of students' scientific literacy is obtained through observations of several indicators of scientific literacy in the form of content, concepts, and processes and cognitive learning outcomes obtained through tests. Based on the results of the analysis of research data that has been done it can be seen that the ability of scientific literacy and student learning outcomes in the experimental class is better than the control class. The average value of cognitive learning outcomes in the experimental class that uses STM learning models is 88, 79 and 80.06 in the control class. Analysis of the significance test through the right-side $t$ test with $\alpha=5 \%$ produces a $t$-test value of 4.82 and a t-table of 2.00 , which means that the cognitive learning outcomes of the experimental class students are better than the control class. Based on the results of these studies, it can be concluded that the application of the STM learning model on the Environmental Pollution Theme is effective at increasing students' scientific literacy abilities
\end{abstract}

Keywords: STM Learning Model and Science Literacy

\begin{abstract}
ABSTRAK
Artikel ini adalah Penelitian kuantitatif bertujuan untuk mengetahui keefektifan pembelajaran dengan menggunakan model pembelajaran Sains Teknologi Masyarakat (STM) pada tema pencemaran lingkungan terhadap peningkatan kemampuan literasi sains siswa kelas VII. Sampel yang diambil adalah siswa MTS Negeri 1 Konsel kelas VII A dan VII C semester genap tahun ajaran 2018/2019. Desain penelitian yang digunakan adalah posttest only control group design, yang menerapkan pembelajaran dengan menggunakan Model pembelajaran STM pada kelas eksperimen dan kelas kontrol yang menerapkan pembelajaran Konvensional. Teknik pengumpulan data yang digunakan adalah teknik pengumpulan menggunakan dokumentasi, observasi dan tes. Data yang diambil adalah hasil observasi pengukuran kemampaun literasi Sains siswa dan hasil belajar. Kemampuan literasi sains siswa diperoleh melalui hasil pengamatan beberapa indikator literasi sains berupa konten, konsep, dan proses serta hasil belajar kognitif yang diperoleh melalui tes. Berdasarkan hasil analisis data penelitian yang telah dilakukan dapat dilihat bahwa Kemampuan literasi sains dan hasil belajar siswa di kelas eksperimen lebih baik dibandingkan dengan kelas kontrol. Rata-rata nilai hasil belajar kognitif pada kelas eksperimen yang menggunakan model pembelajaran STM sebesar 88, 79 dan 80,06 pada kelas kontrol. Analisis uji signifikansi melalui uji t pihak kanan dengan $\alpha=5 \%$ menghasilkan nilai thitung sebesar 4,82 dan ttabel sebesar 2,00 yang artinya hasil belajar kognitf siswa kelas eksperimen lebih baik daripada kelas kontrol. Berdasarkan hasil penelitian tersebut, dapat disimpulkan bahwa penerapan Model pembelajaran STM pada Tema Pencemaran Lingkungan efektif terhadap Peningkatan kemampuan literasi sains siswa
\end{abstract}

Kata Kunci : Model Pembelajaran STM dan Literasi Sains

\section{PENDAHULUAN}

Secara umum istilah sains memiliki arti sebagai Ilmu Pengetahuan. Oleh karena itu, sains didefinisikan sebagai kumpulan pengetahuan yang tersusun secara sistematis, sehingga secara umum istilah sains mencakup Ilmu Pengetahuan Sosial (IPS) dan Ilmu Pengetahuan Alam (IPA). Secara khusus, istilah sains dimaknai sebagai Ilmu Pengetahuan Alam (IPA) atau natural science. Depdiknas menyatakan bahwa Ilmu Pengetahuan Alam (IPA) berkaitan dengan upaya memahami berbagai fenomena alam secara sistematis, sehingga IPA bukan hanya 
penguasaan kumpulan pengetahuan yang berupa fakta-fakta, konsep-konsep, prinsip-prinsip saja, tetapi juga merupakan suatu proses penemuan (Depdiknas,2011)

Pembelajaran Ilmu Pengetahuan Alam (IPA) dikalangan peserta didik masih dianggap sebagai produk, yaitu berupa kumpulan konsep yang harus dihafal sehingga berdampak pada rendahnya kemampuan peserta didik pada aspek koognitif (mengingat, memahami, menerapkan, menganalisis, mengevaluasi dan menciptakan). kecenderungan pembelajaran IPA pada masa kini hanya berorientasi pada produk IPA. Hal ini ditunjukan dengan banyaknya peserta didik yang mempelajari IPA cara menghafal konsep, prinsip, hukum, dan teori. Akibatnya, dimensi sikap, proses, dan aplikasi tidak dapat tercapai secara optimal. Oleh karena itu, perlu dilakukan perubahan dalam pembelajaran IPA (Depdiknas 2011).

Berdasarkan hasil survei dari TIMSS pada tahun 2011 dilaporkan bahwa prestasi belajar IPA siswa kelas VIII di Indonesia berada pada peringkat 40 dari 42 negara peserta TIMSS, dan Data dari hasil survei PISA, menyatakan bahwa pada tahun 2009 kemampuan literasi IPA anak-anak Indonesia usia 15 tahun masing-masing berada pada peringkat 60 dari 65 Negara peserta PISA dengan skor perolehan 383 (Utomo, Y.S, 2011)

Kemampuan literasi sains peserta didik Indonesia dipengaruhi oleh banyak hal, antara lain kurikulum dan sistem pendidikan, pemilihan metode dan model pengajaran oleh guru, sarana dan fasilitas belajar, sumber belajar, bahan ajar, dan lain sebagainya. Salah satu faktor yang secara langsung bersinggungan dengan kegiatan pembelajaran peserta didik yang mempengaruhi rendahnya kemampuan literasi peserta didik Indonesia adalah pemilihan metode dan model pengajaran oleh guru (Fathurrahman dkk,2014)

Pembelajaran sains untuk membangun literasi sains peserta didik dapat dilakukan dengan pembelajaran yang semuanya bertumpu pada "student active learning". Pembelajaran yang berpusat pada peserta didik, sudah pasti berpusat pada proses ilmiah dengan prinsip konstruktivisme.

Salah satu model pembelajaran yang mengusung teori kontruktivisme adalah model pembelajaran Sains Teknologi Masyarakat (STM). (Permanasari, 2011). Model Pembelajaran STM dalam pembelajaran sains merupakan perekat yang mempersatukan sains, teknologi dan masyarakat. pembelajaran dengan model pembelajaran STM berpengaruh tinggi terhadap peningkatan literasi sains dalam pembelajaran IPA (Eviana dkk, 2015). Isu-isu sosial dan teknologi dimasyarakat merupakan karakteristik kunci dari STM (Rai Sujanem, 2009). Isu-isu tersebut dipakai sebagai titik acuan oleh guru untuk merancang dan mengimplementasikan program pembelajaran. Melihat dasar pijakan pengembangan model pembelajaran STM tersebut, maka tidak berlebihan kiranya jika model STM dalam pembelajaran IPA layak dimunculkan sebagai upaya penguasaan konsep peserta didik (Rai Sujanem, 2009).

Oleh karena itu penelitian ini berbeda dengan penelitian yang telah dipaparkan diatas, penelitian ini membahas tentang Pengaruh model pembelajaran STM dalam meningkatkan literasi sains siswa terhadap materi pencemaran lingkungan. Penelitian yang akan dilakukan peneliti bertujuan untuk melihat pengaruh penggunaan model pembelajaran tersebut guna meningkatkan literasi sains siswa, sehingga penelitian ini penting untuk dilakukan karena model pembelajaran ini penerapannya belum pernah dilakukan disekolah yang menjadi lokasi penelitian.

Berdasarkan fakta yang ditemukan oleh peneliti saat melakukan observasi di MTs Negeri 1 Konsel bahwa permasalahan yang didapatkan yaitu hasil belajar IPA siswa kelas VII masih sangat rendah karena tedapat $\pm 50 \%$ siswa yang nilainya belum mencapai kriteria ketuntasan minimal (KKM) yang telah di tentukan yaitu dengan nilai 75. Selain itu siswa masih kurang aktif dan kurang antusias pada saat pembelajaran berlangsung, pemahaman siswa terhadap materi masih sangat rendah dikarenakan pada saat proses pembelajaran guru masih menggunakan pendekatan saintifik dan guru juga kurang memaksimalkan dalam penggunaan modelmodel pembelajaran. Mayoritas guru-guru IPA di MTs Negeri 1 Konsel belum menggunakan model pembelajaran yang bersifat konstruktivisme seperti model pebelajaran STM (MTs Negeri 1 Konsel, 2019). Sehingga peneliti berkeinginan untuk melakukan penelitian dengan judul "Pengaruh Model Pembelajaran STM Dalam Meningkatkan Literasi Sains Siswa Pada Pembelajaran IPA di MTs Negeri 1 Konsel.

\section{METODE PENELITIAN}

Jenis penelitian ini adalah quasi eksperimen. Populasi dalam penelitian ini adalah seluruh peserta didik kelas VII MTsN 1 Konsel yang berdistribusi dalam 4 kelas dengan jumlah siswa sebanyak 127 orang. Adapun penarikan sampel dalam penelitian ini adalah ditetapkan dengan teknik Purposive Sampling artinya menentukan dua kelas dengan pertimbangan tertentu. Pengambilan sampel ini dilakukan dengan pertimbangan bahwa sampel tersebut memiliki kemampuan rata-rata yang Homogen, maka kelas VII A \& VII C sudah dapat mewakili populasi. Kemudian untuk menentukan kelas eksperimen dan kelas kontrol ditentukan nilai Rata-rata yg tinggi sebagai kelas kontrol dan yg rendah sebagai kelas eksperimen (Sukardi., 2013). Desain penelitian ini adalah menggunakan desain Posttest Only Control Group Design, (Sugiyono., 2014).

Analisis statistika deskriptif, yaitu menghitung rata-rata, median, modus, standar deviasi, variansi, distribusi frekuensi, persentse dan kategori. Sedangkan analisis statistika inferensial diawali dengan melakukan uji persyaratan analisis, yaitu; uji normalitas chi kuadrat dan uji homogenitas; uji kesamaan 2 varians (Sugiyono., 2017), selanjutnya untuk pengujian hipitesis digunakan T-test dengan membandingkan nilai thitung 
dan ttabel atau nilai probabilitas $(\rho)$ dengan taraf signifikansi 5\% (Sudjana., 2009) Selanjutnya melakukan interpretasi data dari hasil-hasil pengujian tersebut kemudian menarik kesimpulan dari hasil penelitian.

\section{HASIL PENELITIAN}

\section{Ketuntasan Hasil Belajar Siswa Pada Materi Pencemaran Lingkungan.}

Berdasarkan penelitian yang dilakukan di MTsN 1 Konawe Selatan pada kelas VII A (kelas eksperimen)dan kelas VII C (Kelas Kontrol). Setelah mengikuti proses pembelajaran (3x pertemuan) dengan menggunakan perlakuan dimasing-masing kelas, siswa diminta untuk mengerjakan Posttest, tes pilihan ganda sebanyak 25 nomor, sehingga diperoleh ketuntasan hasil belajar seperti pada Tabel dan Diagram berikut :

Tabel.1 Persentase ketuntasan belajar siswa pada materi pencemaran lingkungan

\begin{tabular}{|c|c|c|c|c|c|}
\hline Kelas & Rata-rata & $\begin{array}{c}\text { Nilai } \\
\text { tertinggi }\end{array}$ & $\begin{array}{c}\text { Nilai } \\
\text { terendah }\end{array}$ & $\begin{array}{c}\text { siswa } \\
\text { tuntas (\%) }\end{array}$ & $\begin{array}{c}\text { siswa tidak } \\
\text { tuntas }(\%)\end{array}$ \\
\hline Eksperimen & 88,79 & 100 & 76 & $100 \%$ & $0 \%$ \\
\hline Kontrol & 80,06 & 88 & 56 & $75 \%$ & $25 \%$ \\
\hline
\end{tabular}

Berdasarkan Tabel. 2 diatas diperoleh nilai persentase ketuntasan belajar siswa yang berbeda antara kelas kontrol dan kelas eksperimen.

\section{Kemampuan Literasi Sains Kelas Eksperimen}

Berdasarkan data yang diperoleh pada kelas eksperimen, diketahui skor tertinggi dan skor terendah adalah masing-masing 100 dan 76 dengan jumlah skor total adalah 2836 dari 32 siswa. Hasil analisis kemampuan literasi sains siswa di MTs Negeri 1 Konsel dengan menggunakan model pembelajaran STM adalah mean dengan nilai 88,79 , median 88 , modus 88 , dan diperoleh distribusi frekuensi kemampuan literasi sains siswa seperti yang ditunjukkan pada tabel.2 berikut :

Tabel.2 Distribusi Frekuensi Kemampuan Literasi Sains Model STM Pada Kelas Eksperimen.

\begin{tabular}{|c|c|c|c|c|c|c|}
\hline Kelas Interval & $\mathrm{Fi}$ & $\mathrm{X}_{\mathrm{i}}$ & $\begin{array}{c}\text { Tipe kelas } \\
(\mathrm{Xi})\end{array}$ & $\mathrm{Zi}$ & $\mathrm{F}_{\mathrm{e}}$ & $\frac{{\text { (fo }-\mathrm{fe})^{2}}^{\mathrm{f}_{\mathrm{e}}}}{}$ \\
\hline $76-80$ & 4 & 78 & 75,5 & $-2,04$ & 2,58 & 0,78 \\
\hline $81-85$ & 6 & 83 & 80,5 & $-1,27$ & 6,58 & 0,04 \\
\hline $86-90$ & 9 & 88 & 85,5 & $-0,50$ & 9,52 & 0,03 \\
\hline $91-95$ & 7 & 93 & 90,5 & 0,26 & 7,85 & 0,093 \\
\hline $96-100$ & 6 & 98 & 95,5 & 1,03 & 3,69 & 1,46 \\
\hline & & & 100,5 & 1,80 & & \\
\hline
\end{tabular}

Berdasarkan kriteria skor yang diperoleh dari analisis data berupa mean (M) dan standar deviasi (SD) Kecenderungan tinggi rendahnya skor kemampuan literasi sains didapatkan 3 kategori dengan ketentuan sebagai berikut:
$\mathrm{X} \geq(\mathrm{M}+\mathrm{SD})$
:Tinggi
$\mathrm{M}-\mathrm{SD} \leq \mathrm{X}<(\mathrm{M}+\mathrm{SD})$
:Sedang
Di bawah (M-SD)
:Rendah (Djemari Mardapi., 2009)

Berdasarkan perhitungan distribusi kecenderungan soal dapat dikategorikan dalam 3 kategori yaitu seperti yang ditunjukkan pada Gambar.1 berikut.

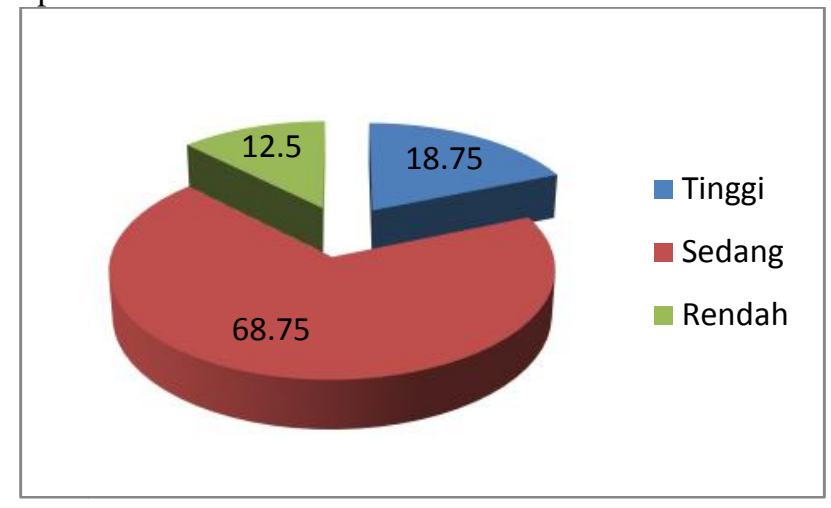

Gambar.1 Diagram kecendrungan kategori kemampuan literasi sains pada kelas eksperimen. 
Berdasarkan Gambar.1 di atas menunjukkan bahwa siswa MTs Negeri 1 Konsel memiliki hasil belajar siswa yang berada pada kategori tinggi sebanyak 6 siswa dengan persentasi $18,75 \%$, kategori sedang sebanyak 22 siswa dengan persentasi $68,75 \%$, dan kategori rendah sebanyak 4 siswa dengan persentasi $12,5 \%$, maka dapat disimpulkan bahwa kecenderungan variabel hasil belajar siswa berada pada kategori tinggi yaitu sebanyak 6 siswa dengan persentasi 18,75\% dari jumlah sampel yang berjumlah 32 siswa.

\section{Kemampuan Literasi Sains Kelas Kontrol}

Berdasarkan data yang diperoleh pada kelas Kontrol diketahui skor tertinggi dan skor terendah adalah masing-masing 88 dan 56 dengan jumlah skor total 2566 dari 32 siswa. Hasil analisis kemampuan literasi sains siswa di MTs Negeri 1 Konsel dengan menggunakan metode pembelajaran saintifik adalah mean dengan nilai 80,06, median 84, modus 84, dan diperoleh distribusi frekuensi kemampuan literasi sains siswa seperti yang ditunjukkan pada tabel.3 berikut:

Tabel.3 Distribusi Frekuensi Kemampuan Literasi Sains dengan Pendekatan SaintifikPada Kelas Kontrol.

\begin{tabular}{|c|c|c|c|c|c|c|}
\hline Kelas Interval & $\mathrm{Fi}$ & $\mathrm{X}_{\mathrm{i}}$ & $\begin{array}{c}\text { Tipe kelas } \\
(\mathrm{Xi})\end{array}$ & $\mathrm{Zi}$ & $\mathrm{F}_{\mathrm{e}}$ & $\frac{{\text { (fo }-\mathrm{fe})^{2}}^{\mathrm{f}_{\mathrm{e}}}}{}$ \\
\hline $76-80$ & 4 & 78 & 75,5 & $-2,04$ & 2,58 & 0,78 \\
\hline $81-85$ & 6 & 83 & 80,5 & $-1,27$ & 6,58 & 0,04 \\
\hline $86-90$ & 9 & 88 & 85,5 & $-0,50$ & 9,52 & 0,03 \\
\hline $91-95$ & 7 & 93 & 90,5 & 0,26 & 7,85 & 0,093 \\
\hline $96-100$ & 6 & 98 & 95,5 & 1,03 & 3,69 & 1,46 \\
\hline & & & 100,5 & 1,80 & & \\
\hline
\end{tabular}

Berdasarkan kriteria skor yang diperoleh dari analisis data berupa mean (M) dan standar deviasi (SD) Kecenderungan tinggi rendahnya skor kemampuan literasi sains didapatkan 3 kategori dengan ketentuan sebagai berikut:
$\mathrm{X} \geq(\mathrm{M}+\mathrm{SD})$
$\mathrm{M}-\mathrm{SD} \leq \mathrm{X}<(\mathrm{M}+\mathrm{SD})$
:Tinggi
:Sedang
Di bawah (M-SD)
:Rendah (Djemari Mardapi., 2009)

Berdasarkan perhitungan distribusi kecenderungan soal dapat dikategorikan dalam 3 kategori yaitu seperti yang ditunjukkan gambar. 2 berikut :

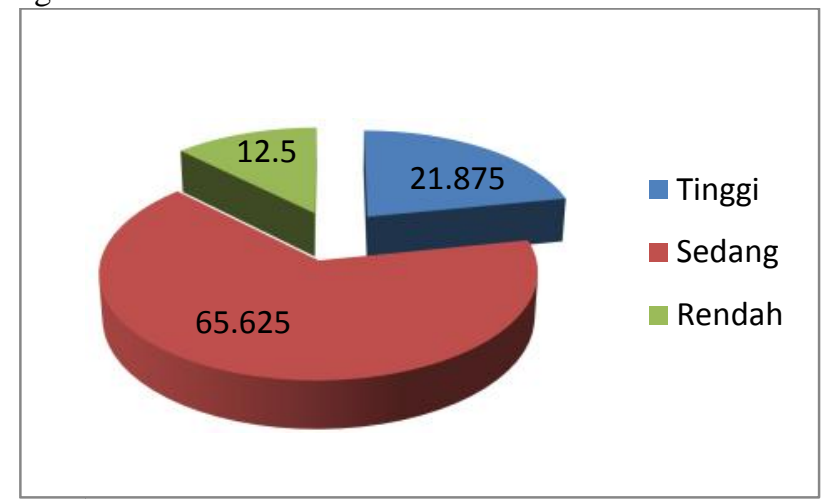

Gambar.2 Diagram kecendrungan kategori kemampuan literasi sains pada kelas eksperimen.

Berdasarkan Gambar.2 terlihat bahwa siswa MTs Negeri 1 Konsel memiliki hasil belajar yang berada pada kategori tinggi sebanyak 7 siswa dengan persentasi 21,87\%, kategori sedang sebanyak 21 siswa dengan persentasi 65,62 \%, dan kategori rendah sebanyak 4 siswa dengan persentasi 12,5\%, maka dapat disimpulkan bahwa kecenderungan variabel hasil kemampuan literasi sains siswa berada pada kategori tinggi yaitu sebanyak 7 siswa dengan persentasi $21,87 \%$ dari jumlah sampel yang berjumlah 32 siswa.

Uji normalitas pada kelas eksperimen (VII A) yang diajar menggunakan model pembeljaran STM, diperoleh nilai $X^{2}$ hitung $=2,403<X^{2}$ tabel $=9,48$, maka data skor hasil belajar pada kelas eksperimen berdistribusi normal. Sedangkan untuk kelompok kontrol (VII C) yang diajar menggunakan pendekatan saintifik, diperoleh nilai $X^{2}$ hitung $=3,72<X^{2}$ tabel $=11,07$, maka data skor hasil belajar pada kelas kontrol berdistribusi normal. Jadi dapat disimpulkan data tersebut berasal dari populasi berdistribusi normal baik pada kelompok eksperimen maupun kelompok kontrol. uji homogenitas diperoleh nilai $F_{\text {hitung }}$ adalah 1,35 sedangkan nilai $F_{\text {tabel }}$ adalah 1,82 dengan taraf signifikansi 0,05. Sehingga $F_{\text {hitung }}<F_{\text {tabel, maka dapat }}$ disimpulkan bahwa populasinya homogen. Kemudian pengujian hipotesis diperoleh $\mathrm{t}_{\text {hitung }}$ sebesar 4,82 dan 
$\mathrm{t}_{\text {tabel }}$ sebesar 2,00, dengan taraf signifikansi 5\% $\mathrm{t}_{(1-\alpha)(32+32-2)}$. Jadi $\mathrm{t}_{\text {hitung }}>\mathrm{t}_{\text {tabel }}$ maka $\mathrm{H}_{\mathrm{o}}$ ditolak, hal tersebut menunjukkan bahwa terdapat perbedaan yang signifikan terhadap hasil belajar siswa pada materi pencemaran lingkungan yang menggunakan model pembelajaran STM dan pendekatan saintifik di MTsN 1 Konsel.

\section{PEMBAHASAN}

Penelitian ini bertujuan untuk mengetahui kemampuan literasi sains siswa yang menggunakan model pembelajaran STM, untuk mengetahui kemampuan literasi sains siswa yang menggunakan pendekatan saintifik, dan untuk mengetahui perbedaan kemampuan literasi sains siswa yang menggunakan model pembelajaran STM dan pendekatan saintifik pada materi pencemaran lingkungan dikelas VII MTsN 1 Konsel. Pada kelas ekperimen diterapkan model pembelajaran STM sedangkan pada kelas kontrol diterapkan pembelajaran sainstifik dengam metode ceramah dan tanya jawab. Pada penelitian ini, dilakukan terlebih dahulu uji prasyarat sampel terhadap pretest dan uji prasyarat analisis terhadap data posttest dari kelas eksperimen dan kelas kontrol. Berdasarkan hasil uji analisis yang diperoleh bahwa data tersebut terdistribusi normal dan homogen. Hal ini menunjukkan bahwa sampel yang diambil memiliki keadaan awal yang sama.

Berdasarkan hasil Observasi dokumentasi tata usaha di MTS Negeri 1 Konsel menunjukkan bahwa rata-rata nilai hasil belajar siswa kelas eksperimen dan kelas kontrol relatif hampir sama. Uji hipotesis menunjukkan tidak terdapat perbedaan yang signifikan antara hasil belajar kelas eksperimen dengan kelas kontrol yakni dengan perolehan nilai rata-rata 72,83 pada kelas eksperimen dan 72,92 pada kelas kontrol. Kelas kontrol dan kelas eksperimen memiliki kemampuan literasi sains yang sama sebelum dilakukan pembelajaran.

Setelah pembelajaran dengan penerapan model pembelajaran STM Pada kelas eksprimen dan penerapan metode belajar saintifik pada kelas kontrol selesai, baik itu pada kelas eksperimen maupun kelas kontrol diberikan tes kemampuan literasi sains (posttest). Hal ini dilakukan untuk mengetahui pengaruh pembelajaran STM dan pembelajaran Saintifik terhadap kemampuan literasi sains siswa pada kelas eksperimen dan kontrol. Berdasarkan Tabel.1 terlihat bahwa rata-rata nilai posttest kelas kontrol lebih kecil dibandingkan dengan kelas eksperimen dengan selisih rata-rata nilai posttest 8,73.

Uji hipotesis menunjukkan terdapat perbedaan yang signifikan antara hasil posttest kemampuan literasi sains kelas eksperimen dengan kelas Kontrol, dengan nilai t hitung sebesar 4,82 dan $\alpha$ sebesar 2,00. Hal ini menunjukkan bahwa pembelajaran STM dapat meningkatkan kemampuan literasi sains siswa pada kelas eksperimen dibandingkan dengan kelas kontrol yang hanya menggunakan metode saintifik pada pembelajaran.

Salah satu alasan yang membuat model pembelajaran STM lebih baik dibandingkan dengan pembelajaran lainya dalam meningkatkan literasi sains siswa pada materi pencemaran lingkungan adalah dapat dilihat dari segi kelebihannya, seperti yang diungkapkan oleh Taufik aditia, salah satu kelebihan STM adalah siswa dapat mempersatuakan sains, teknologi, dan masyarakat, serta isu-isu sosial dan teknologi dimasyarakat merupakan karakteristik kunci dari model pembelajaran STM.

Melalui model pembelajaran STM, para siswa belajar sains dalam konteks pengalaman nyata,yang mencakup penerapan sains dan teknologi. Pengetahuan yang dibangun melalui model pembelajaran STM akan ada pada diri siswa sebagai penerapan di kehidupan nyata (Aditia dan Novianti.,2013). Siswa mengalami pengalaman langsung dengan melakukan pengamatan dalam proses praktikum sehingga kompetensi literasi sains siswa lebih berkembang dibandingkan dengan kelas kontrol (Aditia.,2015).

Capaian kompetensi literasi sains menjelaskan fenomena secara ilmiah menunjukkan bahwa terdapat perbedaan yang signifikan antara rata-rata nilai hasil posttest. Hal ini juga menjelaskan bahwa fenomena secara ilmiah dengan mengangkat isu-isu nyata yang menghasilkan nilai rata-rata yang lebih tinggi dibandingan dengan menggunakan bukti ilmiah dengan metode saintifik. Hal ini terjadi karena pada kompetensi mengidentifikasi permasalahan ilmiah siswa masih dalam bimbingan guru sedangkan pada kompetensi menjelaskan fenomena secara ilmiah siswa lebih mandiri, begitupun dalam menggunakan bukti ilmiah.

Sejalan dengan Farihatul dalam jurnal penelitiannya bahwa capaian aspek proses "menjelaskan fenomena secara ilmiah dengan mengangkat isu nyata" seperti yang diterapkan pada model pembelajaran STM sedikit lebih tinggi dari aspek proses lainnya, karena memang keterampilan proses itu yang cenderung lebih dilatihkan dalam pembelajaran IPA ketimbang keterampilan proses lainnya (Farihatul., 2018).

\section{KESIMPULAN}

Berdasarkan hasil penelitian dan pembahasan yang telah diuraikan sebelumnya, maka dapat diperoleh kesimpulan, bahwa Kemampuan literasi sains siswa yang menggunakan model pembelajaran STM dalam proses pembelajaran memiliki nilai rata-rata sebesar 88,79 dengan kategori tinggi (18,75\%)., sedangkan Kemampuan literasi sains siswa yang menggunakan pendekatan saintifik dalam proses pembelajaran memiliki nilai rata-rata sebesar 80,06 dengan kategori tinggi $(21,87 \%)$. Hal ini membuktikan bahwa terdapat perbedaan Literasi sains siswa yang menggunakan model STM dan kemampuan literasi sains siswa yang menggunakan model konvensional (saintifik), dimana nilai $t_{\text {hitung }} 4,82>t_{\text {tabel }} 2,00$ 


\section{DAFTAR PUSTAKA}

Aditia, Muhammad Taufik, and Novianti Muspiroh. (2013). "Pengembangan Modul Pembelajaran Berbasis Sains, Lingkungan, Teknologi, Masyarakat dan Islam (Salingtemasis) dalam Meningkatkan Hasil Belajar Siswa pada Konsep Ekosistem Kelas X di SMA Nu (Nadhatul Ulama) Lemahabang Kabupaten Cirebon." Scientiae Educatia: Jurnal Pendidikan Sains Vol 2. No 2.

Djemari, Mardapi. (2009). Tekhnik Penyusunan Instrumen Tes Dan Nontes. Yogyakarta: Mitra Cendikia Press.

Laela, Farihatul Faizah Dkk. (2018). Pembelajaran Ipa Menggunakan Concept Attainment Model Dengan Media Riil Dan Media Gambar Ditinjau Dari Kemampuan Berpikir Kognitif Dan Persepsi Kreativitas Siswa. Jurnal INKUIRI ISSN: 2252-7893, Vol. 7, No. 1.

Eviana dkk. (2015). Pengaruh model pembelajaran berbasis masalah terhadap kemampuan literasisains IPA kelas V SD. Jurnal pendidikan dan pembelajaran Vol 1. No 1.

Fathurrahman dkk. (2014). Analisis bahan ajar fisika SMA kelas IX di kecamatan Indramayu Utara berdasarkan kategori literasi sains. jurnal inovasi dan pembelajaran fisika Vol 2 No 3.

Muhajir, Siti. (2015). Perbedaan Penerapan Model Pembelajaran STS Dan CTL Terhadap Literasi Sains Dan Prestasi Belajar IPA. Jurnal Pendidikan Matematika Dan Sains Thn III. No.2

Permanasari, A. (2011). Pembelajaran Sains : Wahana Potensial Untuk Pembelajaran Soft Skill dan Karakter. Jurnal Universitas Lampung.

Sudjana, Nana dan Ibrahim. (2009). Penelitian Dan Penilaian Pendidikan. Bandung : sinar Baru Algesindo.

Sudjana, Nana. (2009). Metode Statistika. Bandung : PT Tarsito

Sugiyono. (2017). Metode Penelitian Pendidikan Pendekatan Kuantitatif, kualitatif, dan R\&D. Bandung : Alfabeta, cv.

Suharsimi, Arikunto. (2008). Dasar-dasar Evaluasi Pendidikan, Jakarta : Bumi Aksara ed. Revisi, cet 8.

Sujanem, Rai. (2009). Penerapan Bahan Ajar Yang Berwawasan Pendekatan STM Sebagai Upaya Untuk Meningkatkan Kualitas Pembelajaran Praktikum Fisiska Dasar, Sikap Ilmiah, Lerasi Sains, Dan Teknologi Mahasiswa Pendidikan MIPA STKIP Singaraja. Aneka Widya IKIP Negeri Singaraja No. 1 Th. XXXV.

Sukardi. (2013). Metodologi Penelitian Pendidikan Kompetensi dan Praktiknya. Jakarta : PT Bumi Aksara.

Utomo, Y.S. (2011). Survey Internasional Timss. 